\title{
Oil Spill Incidents and Their Impacts to Fisheries and Tourism Activities in Kepulauan Seribu
}

\author{
Mohammad Abdul Jabbar..*. Tri Edhi Budhi Soesilo²dan Udi Syahno Edi Hamzah² \\ ${ }^{1}$ Magister Program of Environmental Science Universitas Indonesia. Salemba. Jakarta. 10430. \\ Indonesia \\ ${ }^{2}$ Environmental Science Universitas Indonesia. Salemba. Jakarta. 10430. Indonesia
}

\begin{abstract}
Kepulauan Seribu is a group of islands located in the north of Jakarta. which consist of several sensitive areas such as National Marine Park. settlement. coral reefs. fisheries. and tourism areas. The activities of oil \& gas industries and shipping lanes in Kepulauan Seribu could potentially lead to oil spill pollution to waters and coast of Kepulauan Seribu which causing damage to sensitive areas. Past incidents of oil spills in Kepulauan Seribu has causing damages to fisheries. corals reef. and tourism activities. Therefore. appropriate oil spill preparedness and response are required since they are they are regulated by government and are important measures to minimize the negative impacts of an oil spill.
\end{abstract}

\section{Introduction}

Kepulauan Seribu is a group of islands located in the north of Jakarta. the islands are made from coral reef islands and formed by coral biota and its associates (algae. malusho. foraminifera) with the help of natural dynamics processes[1].Kepulauan Seribu is a popular tourist destination. since these islands are one of the first officially protected marine areas in Indonesia. The development of Kepulauan Seribu is to increase tourism activities. improve the quality of life of fishing communities through increased marine cultivation. and utilization of fisheries resources by conserving coral reef and mangrove ecosystems[2].

Kepulauan Seribu waters is one of the Indonesian Archipelago Sea Lines. thus the international and domestic ships including tankers are passing through this area[3]. and also there are two major upstream oil companies in Kepulauan Seribu [4]. [5]. Therefore. the risk of oil spills from human activities which can damage the environment will always threaten the sustainability of Kepulauan Seribu. This is proven by several oil pollutions which occurred in Kepulauan Seribu these 10 recent years which resulted in environmental damage and community losses. namely the loss of fish cultivation. damage to mangrove ecosystems. and the reduction of hawksbill turtles[6]. Therefore. appropriate oil spill

\footnotetext{
*Corresponding author:mohammad.abdul@ui.ac.id
} 
preparedness and response are required since they are they are regulated by government and are important measures to minimize the negative impacts of an oil spill.

\subsection{Sensitive Resources in Kepulauan Seribu}

\subsubsection{Fisheries}

The spread of marine fishing areas in Indonesia that reaches approximately 5.8 million $\mathrm{km}^{2}$ and marine aquaculture with approximately 120 thousand $\mathrm{km}^{2}[7]$. making the utilization of marine resources especially on fisheries main source of livelihood of people who lived on the coastal islands. Fishery productions in Kepulauan Seribu have provided many benefits to local fishermen. The production value for marine water fisheries and marine aquaculture in Kepulauan Seribu in 2012 is IDR 63.660.000; in 2013 is 57.183.000; and in 2016 has reached 229.130.000[1].

\subsubsection{Tourism Areas}

Kepulauan Seribu has ecotourism potential located throughout the islands. the potential of which is a major activity in the development of marine ecotourism [8]. Kepulauan Seribu is famous for its coastal tourism. In this area. besides fishing and swimming. tourists can also admire the beauty of the shallow underwater world with diving activities [9]. Tourism activities that can be carried out in this area are diving. snorkelling. swimming. fishing. water skiing and outbound. and also research activities on coral transplantation. seagrass planting. mangroves. rehabilitation of corals. hawksbill turtles. and indigenous eagles [10].

Table 1.Number of tourist visit in KeuplauanSeribu 2005-2016[1]

\begin{tabular}{|c|c|c|c|c|}
\hline No & Tourims Area & $\begin{array}{c}\text { Foreign } \\
\text { (person) }\end{array}$ & $\begin{array}{c}\text { Domestic } \\
\text { (person) }\end{array}$ & $\begin{array}{c}\text { Total } \\
\text { (person) }\end{array}$ \\
\hline 1 & UntungJawa Island & 82 & 232.587 & 232.669 \\
\hline 2 & Pramuka Island & 850 & 88.078 & 88.928 \\
\hline 3 & Tidung Island & 1.587 & 144.764 & 146.351 \\
\hline 4 & Harapan Island & 850 & 82.256 & 86.106 \\
\hline 5 & Lancang\& Pari Island & 1.369 & 114.738 & 116.107 \\
\hline
\end{tabular}

\subsection{Potential and Impacts of Oil Spill}

\subsubsection{Oil Spill Risk Potential}

The occurrence of an oil spill can be caused by ship collision. ship grounding. hull damage. failure of loading-unloading system. well blow out. fire. offshore installation failure. and oil transportation [11]. The oil spill incidents at sea are often occur in the shipping lanes and offshore installation [12]. In Indonesia based on Ministry of Energy and Mineral Resources. the oil spill has occurred for the total of 3.373 barrels of oil released to the environment from the oil and gas activities since 2011 to 2015[13]. 
Table 2.Oil spill from oil and gas activities in Indonesia[13]

\begin{tabular}{|c|c|c|c|c|c|}
\hline \multirow{2}{*}{ Operation } & \multicolumn{5}{|c|}{ Year } \\
\cline { 2 - 6 } & 2011 & 2012 & 2013 & 2014 & 2015 \\
\hline Hulu & 181.80 & 197.60 & 2.071 .37 & 46.70 & 91.38 \\
\hline Hilir & 0.00 & 0.16 & 0.00 & 0.00 & 784.00 \\
\hline Total (Barrel) & 181.80 & 197.76 & 2.071 .37 & 46.70 & 875.38 \\
\hline
\end{tabular}

Inside the area of Kepulauan Seribu. there some activities which can potentially lead to an oil spill pollution:

a) Shipping lane; The marine area of Kepulauan Seribu is one of the Indonesian Archipelago Sea Lines. thus becoming a shipping line for domestic and international vessels [3].

b) Upstream oil and gas industry; There are two upstream oil \& gas company which are PHE ONWJ and CNOOC SES Ltd. These companies operating the subsea pipeline and floating storage offloading which has the potential for oil spill release from their operation [4]. [5].

\subsubsection{Impact of Oil Spills}

Oil spills can cause great environmental damage and have a direct impact on marine organisms[14]. human safety and health. coastal pollution and ecosystem[15-18]. In Hebei Spirit oil spill incident which occurred in Korea on 2007 the fishery community has suffered losses from degradation of species. biomass. and diversity for 2 years [19]. Hebei Spirit oil spill also has caused health problems in the form of visual disturbances. nose and bronchial irritation. headaches. heart disease. fatigue and fever. memory and cognitive disorders. and abdominal pain. and ecosystem damage due to high toxicity of hydrocarbons in soil and water [20]. similar damages also occurred in Exxon Valdez oil spill incident in Alaska on 1989 and British Petroleum oil spill incident in Gulf of Mexico on 2010 [21].

\subsection{Oil Spill Preparedness and Response}

\subsubsection{Government Regulation}

The national law of environment No.32 year 2009 about the protection and the management of environment states that every person who carries out environmental pollution and/or damage is obliged to handle the pollution and/or damage and is obliged to restore the environmental functions. The president's regulation No.109 year 2006 about the response of oil spill emergency situation at sea states that each company/unit/person is obliged to cope with the occurrence of an emergency oil spill in the sea originating from its business and/or activities. Transportation Minister Regulation No.58 year 2013 about the prevention of pollution in the waters and ports. states that each unit/company. oil storage facility in the waters. and port activities must fulfill the pollution prevention requirements. namely which are procedure. personnel. equipment. and conducting exercise.

\subsubsection{Oil spill preparedness and preparedness}

One of the most important steps in any disaster is to prepare. so it can help minimizing the potential hazards to human health and environment by ensuring timely and coordinated countermeasures[22]. The preparedness in oil spill are preparing the procedure. response equipment and supporting resources. personnel formed in the response team. and 
conducting regular oil spill exercises[11]. The oil spill preparedness above is mandatory to be fulfilled by each company which operates in port or waters based on the Indonesian regulations.

An effective oil spill response requires a strategy and implementation that is adjusted to the condition of the spill that occurs. sensitive environment that might be affected. and other efforts that can be done to prevent or minimize the impact of the oil spill [17]. In an effective management of oil spill response. it is very important to actively engage stakeholders such as government agencies. community organizations. industries. and independent contractors to ensure that they support the strategies and tactics previously planned to be implemented in the event of an oil spill [23]. It can be concluded that they are all important to work together in effective manner for successful countermeasures.

\section{Materials and Methods}

The method used in this paper is descriptive method with quantitative approach. Secondary data or literature sources such as books. papers. and reports are used to describe the historical spill events and their negative impacts to sensitive resources in KepulauanSeribu. and also regulations related to oil spill in Indonesia.The output of this paper is to give awareness about the risk of oil spill in Kepulauan Seribu and can be used as a reference for further research to mitigate the oil spill impacts in Kepulauan Seribu.

\section{Results and Discussions}

Table 3. Oil spill incident which occured in Kepulauan Seribu 2003-2018

\begin{tabular}{|c|c|c|c|}
\hline No & Time & Source & Impacted shoreline \\
\hline 1 & 2003 & Unknown & Pramuka Island and National Park \\
\hline 2 & February 2006 & Unknown & Kotok Island \\
\hline 3 & October 2008 & Unknown & $\begin{array}{c}\text { Pari Island. Tikus Island. Burung } \\
\text { Island. and Payung Island }\end{array}$ \\
\hline 4 & 2 November 2009 & Offshore Installation & PramukaIsland and Taman Nasional \\
\hline 5 & October 2015 & TB. Mitra Anugrah & $\begin{array}{c}\text { Bokor Island. Untung Jawa Island. } \\
\text { Pari Island and Lancang Island. }\end{array}$ \\
\hline 6 & 11 April 2016 & Passing ship & Karya Island. Panggang dan Pramuka \\
\hline 7 & 6 October 2017 & Unknown & Pari Island \\
\hline 8 & 8 October 2017 & Unknown & Air Island \\
\hline 9 & 31 October 2017 & Unknown & Panggang and Pramuka Island \\
\hline 10 & 1 November 2017 & Unknown & PanggangIsland and Pramuka Island \\
\hline 11 & 3 November 2017 & Unknown & $\begin{array}{c}\text { Tidung Island. Kelapa Island. } \\
\text { Panggang Island. and Pramuka Island }\end{array}$ \\
\hline 12 & 8 April 2018 & Offshore Installation & Pari Island \\
\hline
\end{tabular}

\section{Conclusions}

Oil spills have been occurred in Kepulauan Seribu with frequent event sand causing the negative impacts to sensitive areas in Kepulauan Seribu such as fisheries. corals. and tourism areas. Therefore. appropriate preparedness and response are important measures to be provided based on risk assessment and government regulations in order to minimize the negative impacts of an oil spill in Kepulauan Seribu.The discussions in this paper are limited to the historical spill events and their impacts to the sensitive areas in 
KepulauanSeribu. Assessment of oil spill risk. evaluation of preparedness status and response performed in past incidents in Kepulauan Seribu are further researches required to be carried out to gain more awareness of all stakeholders on the risk of oil spills in Kepulauan Seribu so it can be avoided or minimized. and maintain the sustainability of sensitive resources in Kepulauan Seribu.

\section{Acknowledgments}

This work was supported by the Direktorat Riset dan Pengabdian Kepada Masyarakat (DRPM) Universitas Indonesia through the program of Hibah Publikasi Internasional Teindeks Untuk TugasAkhir Mahasiswa Tahun 2018 with Contract Number 2585/UN2.R3.1/HKP.05.00/2018.

\section{References}

1. BPS Kabupaten Kepulauan Seribu (BPS Kep. Seribu). Kepulauan Seribu dalam angka 2017 (Jakarta. 2017)

2. S. Y. Cahyarini. J. Zinke. S. Troelstra. Suharsono. E. Aldrian. and B. W. Hoeksema. J. Mar. Pollut. Bull 110, 2 (2016)

3. Sabhan. Model Sebaran Tumpahan Minyak Di Alur Pelayaran Kepulauan Seribu DKI Jakarta (Institut Pertanian Bogor. 2011)

4. Badan Pengelolaan Lingkungan Hidup Daerah Provinsi DKI Jakarta (BPLHD DKI). .Status lingkungan hidup Daerah DKI Jakarta (Jakarta. 2015)

5. SKK Migas, Peta Wilayah Kerja Migas Republik Indonesia Tahun 2018. https://skkmigas.go.id/detail/1090/peta-migas (2018)

6. K. Kuncowati. J. Apl. Pelayaran dan Kepelabuhanan 1, 1 (2010)

7. BPS. Statistik sumber daya laut dan pesisir 2017 (Badan Pusat Statistik Indonesia. Jakarta. 2017)

8. L. Noviana and L. Febrina. J. Br. J. Appl. Sci. Technol 18, 6 (2016)

9. H. Aryunda. J. Perenc. Wil. dan Kota 22, 1 (2011)

10. Kementerian Kelautan dan Perikanan (KKP). Profil Kawasan Konservasi Provinsi DKI Jakarta (Direktorat Jenderal Kelautan. Pesisir dan Pulau-Pulau Kecil. Kementerian Kelautan dan Perikanan. 2015)

11. IMO. Manual on Oil Spill Risk Evaluation and Assessment of Response Preparedness. (London. International Maritime Organization. 2010)

12. M. R. Putri. A. Setiawan. T. Sari. B. Mayer. and T. Pohlmann. J. Ilmu dan Teknol. Kelaut. Trop 9, 2 (2017)

13. Direktorat Jenderal Minyak dan Gas Bumi (Ditjen Migas). Statistik Minyak dan Gas Bumi 2015 (Kementerian Energi dan Sumber Daya Mineral. 2016)

14. A. Farmer. Managing Environmental Pollution (New York. Routledge. 1997)

15. J. W. Farrington. J. Environ. Sci. Policy Sustain. Dev 56, 4. (2014)

16. M. Grote. A. Nagel. H. Nies. J. Rauterberg. and D.-S. Wahrendorf. The Use of Dispersants to Combat Oil Spills in Germany at Sea (Federal Institute for Risk Assessment. Berlin. 2016)

17. IMO. Manual on Oil Pollution Section IV: Combating Oil Spills (International Maritime Organization. London. 2005)

18. ITOPF. Effects of Oil Pollution on the Marine Environment (ITOPF Technical 
Information Paper (TIP) 13. 2011)

19. U. H. Yim. J. S. Khim. M. Kim. J. H. Jung. and W. J. Shim. J. Arch. Environ. Contam. Toxico, 73. 1 (2017)

20. D. Jung. J. A. Kim. M. S. Park. U. H. Yim. and K. Choi. J. Chemosphere 173. (2017)

21. L. Li. B. Wang. and A. Wang. J. Manag. Anal 1. 2 (2014)

22. G. Atighechian. M. R. Maleki. A. Aryankhesal. and K. Jahangiri. J. Desalin. Water Treat 57. 58 (2016)

23. IPIECA-IOGP. Contingency planning for oil spills on water (IOGP Report 519. 2015)

24. Dinas Lingkungan Hidup DKI Jakarta (Dinas LH DKI Jakarta). J. Dinas Lingkungan Hidup Kabupaten Kepulauan Seribu (2017). 